\title{
Advanced Calculation Model of V-Belt Temperature Field
}

\author{
Baoyan Xu, Yehong Liu, Yuan Wang, Xindong Ni, Xin Wang" \\ Beijing Key Laboratory of Optimized Design for Modern Agricultural Equipment, College of \\ Engineering, China Agricultural University (East Campus), \\ Beijing, China \\ wangxin117@cau.edu.cn
}

\begin{abstract}
In the process of continuous high-strength operation of the harvester, structure aging, surface hardening, brittle fracture, and other features appear on V-belt due to temperature rise, which seriously affects the service life of the belt and stability of the whole machine. To predict the temperature distribution of $\mathrm{V}$-belt and improve its service life, an advanced calculation method of temperature field suitable for multiwheel is proposed. First, on the basis of analysing the heat source of the transmission belt, the values of internal friction and external friction are calculated based on AVL Excite Timing Drive (AVL Excite TD). Secondly, two-dimensional temperature field finite element calculation model is established by analysing the heat balance equation, determining the heat flow distribution coefficient and heat convection conditions. Then, to verify the calculation model of the temperature field, the experimental setup and instrumentation are built based on Controller Area Network-bus (CAN-bus) technology. At last, multi-condition tests are designed in this paper. The experiment results show that the maximum difference between the model calculated value and experiment is $4.77^{\circ} \mathrm{C}$ in unsteady state, and $0.15{ }^{\circ} \mathrm{C}$ in steady state. Therefore, the multiwheel $\mathrm{V}$-belt temperature field calculation model developed in this paper can realize the accurate calculation of the temperature field under steady state conditions. It has a very important guiding significance for reasonable selection of operating parameters and improvement of service lifetime of belt.
\end{abstract}

Index Terms -Power loss; V-belt; Combine harvester; Finite element; Temperature field.

\section{INTRODUCTION}

Belt drives are widely used in agricultural machinery because of its simple structure, smooth transmission, and vibration absorption. As one of the most complex and high-tech agricultural machinery, combine harvester integrates collecting, cutting, threshing, separation, and other harvesting processes [1], [2]. V-belt is a kind of friction transmission belt, which is an important medium of power transmission between multi-functional rotating parts of a combine harvester. However, in the process of continuous high-strength operation of the harvester, structure aging, surface hardening, brittle fracture, and other features appear on V-belt due to temperature rise, which seriously affects the

Manuscript received 10 October, 2020; accepted 30 April, 2021.

This research was funded from the National Key Research and Development Program of China under Grant No. 2017YFD0700603. service life of the belt and stability of the whole machine [3], [4]. Therefore, the research on the temperature field of V-belt is of great significance to improve its service life and reduce the failure rate of harvester.

There is a strong correlation between dynamic heat generation and power losses of the belt drive. Existing research mainly focuses on theoretical modelling and experimental optimization methods of power losses. Based on the linear theory of elasticity, the calculation model of flat belt power losses was established by Gerbert [5]. To predict the internal friction power losses of Front Engine Accessory Drive (FEDA), theoretical models of belt hysteresis losses caused by dynamic bending, shear, flank, stretching, and radial compression of the belt rubber were established by Manin, Silva et al. based on the viscoelastic theory of rubber materials [6]-[8]. Furthermore, for improving the theoretical model of total power losses of FEDA, external losses, such as belt-pulley slip and bearings friction, were modelled and implemented based on the theory of elastic sliding [9]. An optimization method based on a genetic algorithm was developed by Silva et al. on the basis of total power losses model to optimize the power losses of FEDA and reduce the engine fuel consumption [10]. To predict the speed losses of V-ribbed belt drives, one-factor-at-a-time (OFAT) test method and response surface method (RSM) were utilized by Balta, Sonmez, and Cengiz to investigate the slip behaviour of a V-ribbed belt drive, and the accuracy of prediction model was verified by experiment under any working condition [11]. In addition, Childs and Cowburn studied the influence of angle mismatch between the pulley and belt wedge on power losses through experiments [12], [13].

Thus far, although there are some reports about the temperature field of the belt drive system, only two studies have attempted to investigate the temperature field of belt An advanced thermal model was proposed by Liu and Behdinan to calculate the temperature distribution of a serpentine belt drive at static state operating conditions, yet it focuses on the calculation of pulley temperature field [14], [15]. Finite element simulation model was developed by $\mathrm{Xu}$, Liu, Y. Wang, S. Wang, and X. Wang to predict the temperature distribution of the belt, but it only aimed at two-wheel V-ribbed belt drive system and did not explore the factors affecting the temperature field of the belt [16].

Therefore, there are two primary aims of this study: one is 
to extend the calculation model and method of temperature field from two-wheel V-ribbed belt system to multiwheel $\mathrm{V}$-belt system, and the other is to explore the influence of operating parameters of the transmission system on the temperature field through experiments. Firstly, on the premise of analysing the heat source of transmission belt, this paper establishes the power losses model and heat source value of V-belt of 4LZ-6A combine harvester based on AVL Excite TD. Secondly, single factor simulation prediction of temperature field is carried out by using the finite element method. Finally, the correctness of the calculation model of the temperature field is verified by the single factor test.

\section{AnAlysis AND CALCUlation OF Heat Source of V-BELT TEMPERATURE FIELD}

\section{A. Heat Source Analysis of Temperature Field}

There are two forms of power losses in belt drive: one is characterized by speed losses [11], [17], [18] and torque losses [19]-[21], and the other is characterized by internal friction loss [6], [8] and external friction loss [6], [9]. The latter constitutes the heat source of the temperature field of the transmission belt.

\section{Internal Friction Heat Source}

V-belt is composed of top fabric, top rubber, buffer layer, tensile member, and bottom rubber, as shown in Fig. 1. Top fabric is covered around V-belt to protect it from abrasion and erosion. Buffer layer is wrapped around the tensile member and absorbs the impact force of the tensile member during the operation of the transmission belt [22]. Tensile members bear the tensile load of V-belt. Top and bottom rubber are made of synthetic rubber, which can increase the friction area between V-belt section and wheel groove and improve the transmission efficiency. Due to the low modulus, large deformation, and dynamic viscoelasticity of rubber, the stress of V-belt cannot keep up with the change of strain when subjected to periodic random dynamic load. Friction heat is generated between rubber molecules [23], [24]. According to different forms of heat sources, internal friction heat sources are divided into dynamic bending, shear, flank, stretching, and radial compression of the belt rubber [7], [8]. However, the power losses test data of FEDA by Silva, Manin et al. showed that dynamic bending constitutes the majority of the internal friction heat source [6], [8], [9]. Therefore, this paper ignores the contribution of the shear, flank, stretching, and radial compression of the rubber belt to the internal friction heat source.

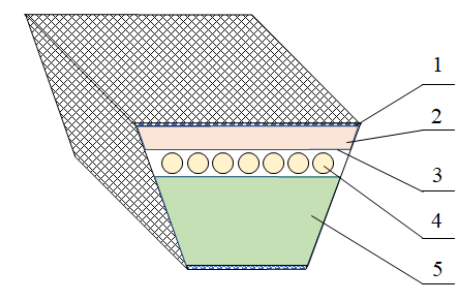

Fig. 1. Structure diagram of V-belt: 1 - top fabric, 2 - top fubber, 3 - buffer layer, 4 - tensile member, 5 - bottom rubber.

During the load transfer process, V-belt is periodically wound in and out of the pulleys. On account of the limitation of pulley geometry, V-belt will be bent and spread periodically. In different parts of the drive system, the top and bottom rubber of $\mathrm{V}$-belt are subject to different bending loads, as shown in Fig. 2.

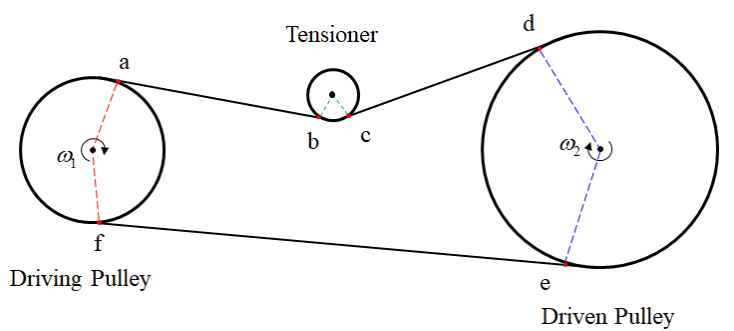

(a)

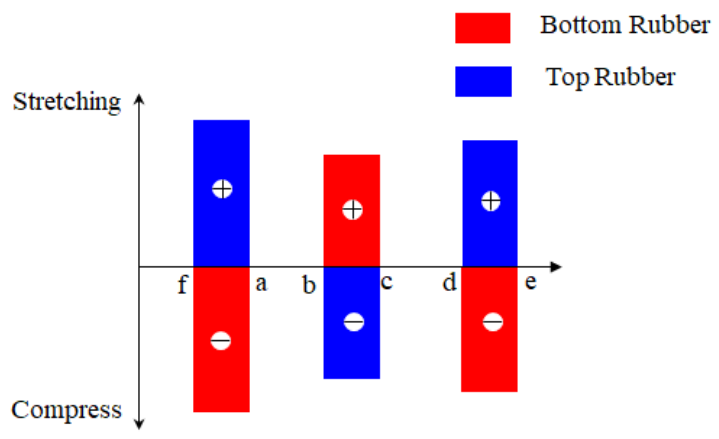

(b)

Fig. 2. Diagram of bending load of top and bottom rubber: (a) diagram of two-wheel drive system and (b) diagram of top and bottom rubber bending load.

When V-belt passes through the driving pulley or driven pulley (i.e., the arcs of $d e$ and $f a$ in Fig. 2(a)), the top rubber is subjected to tensile load and bottom rubber is subjected to compressive load. However, when V-belt is wound into a tensioner, the top and bottom rubber are subjected to the opposite bending load (i.e., the arcs of $b c$ in Fig. 2(a)). The periodic bending strain of the top and bottom rubber of V-belt leads to intermolecular friction and heat generation.

\section{External Friction Heat Source}

Due to the tension stress of the tight side and slack side of $\mathrm{V}$-belt is not equal, the strain on both sides of $\mathrm{V}$-belt is not equal, resulting in a small amount of relative sliding between the belt and pulleys [25]. The tensile stress of V-belt is shown in Fig. 3. On the contact arc of the driving pulley, when $\mathrm{V}$-belt moves from point $\mathrm{g}$ to point $\mathrm{a}$, the tension on $\mathrm{V}$-belt decreases gradually from $F_{t}$ to $F_{s}$. At the same time, the elastic elongation of $\mathrm{V}$-belt gradually decreases. As a result, $\mathrm{V}$-belt retracts relative to the driving pulley.

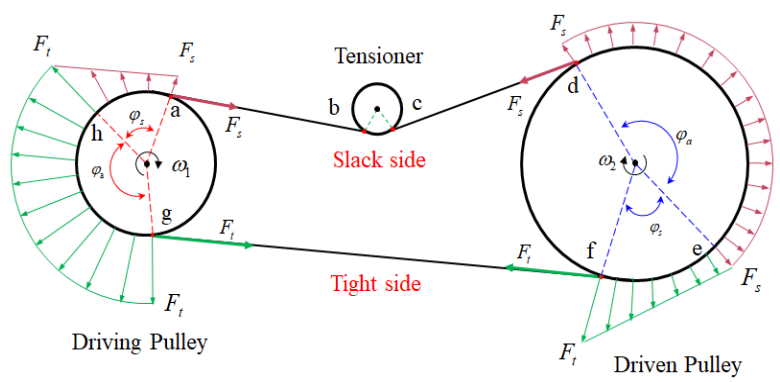

(a) 


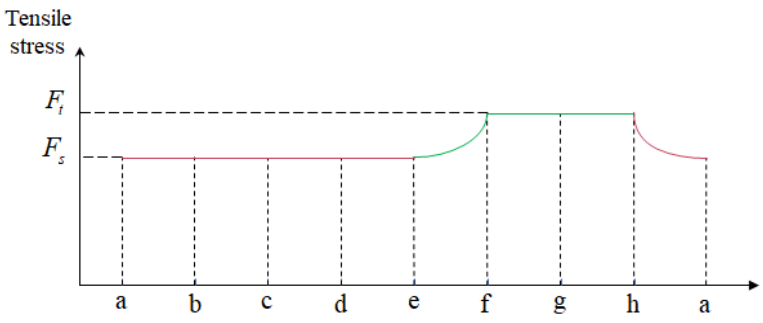

(b)

Fig. 3. Tensile stress diagram of V-belt: (a) Overall stress distribution diagram of V-belt; (b) Time history stress diagram of V-belt.

On the contact arc of the driven pulley, when V-belt moves from point $\mathrm{d}$ to point $\mathrm{f}$, tension on the belt gradually increases from $F_{s}$ to $F_{t}$, and the elastic elongation of $\mathrm{V}$-belt increases gradually. Therefore, V-belt moves forward relative to the driven pulley. The relative sliding between $\mathrm{V}$-belt and pulleys results in external friction and heat.

\section{B. Heat Source Calculation Model}

There are two methods to calculate the heat source of temperature rise of transmission belt: one is to try to establish the power loss spectrum of the transmission belt through theoretical calculation from the perspective of material properties of rubber dynamic hysteresis heat generation, and the other is to indirectly calculate the power loss of transmission belt through Automatic Dynamic Analysis of Mechanical Systems (ADAMS). However, both of these methods are for the FEAD system. Therefore, this chapter attempts to use another dynamic analysis software to directly calculate the heat source of the harvester transmission belt.

AVL Excite TD is a general dynamic analysis software, which can complete the modelling, simulation analysis, and power loss calculation of the belt drive system in a short time [16]. Therefore, the modelling of multiwheel transmission system is constructed in AVL Excite TD to calculate the heat source of bending internal friction and sliding external friction. The calculation process is divided into three steps: 1) Setting the physical parameters of the transmission system; 2) Setting parameters of the tensioning mechanism; 3) Driving wheel speed and driven pulley load are applied to calculate the heat source.

\section{Setting Physical Parameters of Transmission System}

The physical parameters mainly include the relative position and size of pulleys, dynamic characteristic parameters of $\mathrm{V}$-belt, and friction contact parameters between V-belt and pulleys. V-belt drive system of 4LZ-6A combine harvester is composed of a driving pulley, driven pulley 1 , idler pulley, driven pulley 2 , tensioner, as shown in Fig. 4. Driving pulley is driven by the engine, and power is transmitted to each pulley through V-belt. Tension of V-belt is controlled by a tensioner. Wrap angle of the driven pulleys are optimized by idlers. In the calculation model, the pulleys are regarded as a rigid body [26]. The physical property parameters of the pulleys are shown in Table I.

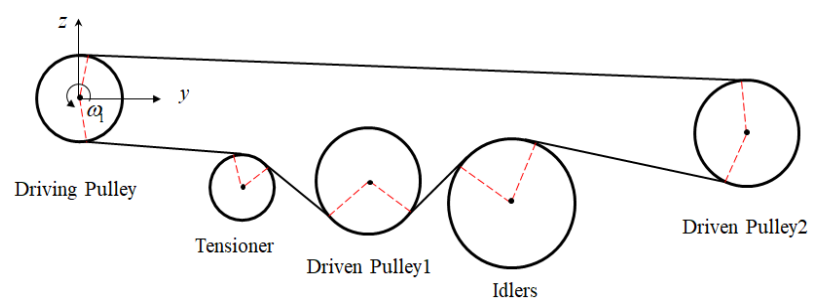

Fig. 4. V-belt drive system of 4LZ-6A combine harvester.

TABLE I. PHYSICAL PROPERTY PARAMETERS OF PULLEYS.

\begin{tabular}{|c|c|c|c|c|c|c|}
\hline Element & $\begin{array}{l}\text { Pitch Diam. } \\
\quad(\mathbf{m m})\end{array}$ & $\begin{array}{l}\text { Position Coordinates } \\
\text { (mm, mm) }\end{array}$ & $\begin{array}{c}\text { Moment of } \\
\text { Inertia }\left(\mathrm{Kg} \times \cdot \mathrm{m}^{2}\right)\end{array}$ & $\begin{array}{c}\text { Thermal } \\
\text { Conductivity } \\
\left(\mathrm{mW} / \mathrm{mm} \times{ }^{\circ} \mathrm{C}\right)\end{array}$ & $\underset{\left(t \cdot \times \mathbf{m m}^{-3}\right)}{\text { Density }}$ & $\begin{array}{c}\text { Specific Heat } \\
\text { Capacity } \\
\left(\mathrm{mJ} / \mathrm{t} \times{ }^{\circ} \mathrm{C}\right)\end{array}$ \\
\hline Driving Pulley & 133.5 & $(0.0,0.0)$ & 0.09 & 36 & $7.8 \times 10^{-9}$ & $4.6 \times 10^{8}$ \\
\hline Ideal & 254.0 & $(910.5,-206.0)$ & 0.70 & 36 & $7.8 \times 10^{-9}$ & $4.6 \times 10^{8}$ \\
\hline Driven Pulley 2 & 168.0 & $(1410.5,-92.0)$ & 0.13 & 36 & $7.8 \times 10^{-9}$ & $4.6 \times 10^{8}$ \\
\hline Tensioner & 132.0 & $(4355.0,200.0)$ & 0.05 & 36 & $7.8 \times 10^{-9}$ & $4.6 \times 10^{8}$ \\
\hline
\end{tabular}

V-belt is an important medium of power transmission. In the calculation model, $\mathrm{V}$-belt is discretized into series rigid elements and flexible elements [26], as shown in Fig. 5.

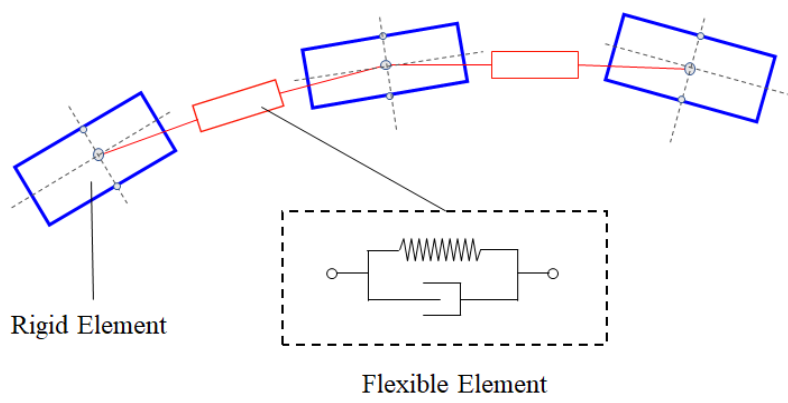

Fig. 5. Discrete model of V-belt.

Rigid elements have inertial properties. Flexible elements are composed of massless spring and damping, which represent the viscoelastic characteristics of V-belt [27]. In the process of modelling, it is necessary to input the physical and dynamic parameters of V-belt. The physical parameters of V-belt include top width, band height, linear density, length discrete number, and thermal conductivity. The dynamic parameters of V-belt include tensile stiffness, bending stiffness, tensile damping, and bending damping. According to the national standard ISO 4183:1995 "Belt drives Classical and narrow V-belts - Grooved pulleys (system based on datum width, MOD)" and work in [23], the parameters of $\mathrm{V}$-belt are determined as shown in Table II.

The contact between V-belt and pulley is instantaneous. Contact force is expressed by the collision function model based on Hertz elastic contact theory [28], [29]

$$
F_{\mathrm{N}}=k_{\mathrm{c}} \delta^{e}+\operatorname{step}\left(\delta, 0,0, \delta_{\mathrm{p}}, c_{\mathrm{p}}\right) \dot{\delta},
$$

where $k_{c}$ is the contact stiffness, $\delta^{e}$ is the compression deformation, $\quad e$ is the contact force index, $\dot{\delta}$ is the deformation velocity, $c_{p}$ is the maximum contact damping 
coefficient, and $\delta_{p}$ is deformation when the maximum damping coefficient is reached.

TABLE II. PHYSICAL PROPERTIES AND DYNAMIC PARAMETERS OF V-BELT.

\begin{tabular}{|c|c|c|c|}
\hline $\begin{array}{c}\text { Physical } \\
\text { Properties } \\
\text { Parameters }\end{array}$ & Value & $\begin{array}{c}\text { Dynamic } \\
\text { Parameters }\end{array}$ & Value \\
\hline $\begin{array}{c}\text { Top Width } \\
(\mathrm{mm})\end{array}$ & 17.0 & $\begin{array}{c}\text { Tensile Stiffness } \\
\left(\mathrm{N} \times \mathrm{m}^{2}\right)\end{array}$ & $8.4 \times 10^{5}$ \\
\hline $\begin{array}{c}\text { Band Height } \\
(\mathrm{mm})\end{array}$ & 13.0 & $\begin{array}{c}\text { Bending Stiffness } \\
\left(\mathrm{N} \times \mathrm{m}^{2}\right)\end{array}$ & $8 \times 10^{-4}$ \\
\hline $\begin{array}{c}\text { Linear Density } \\
\left(\mathrm{Kg} \times \mathrm{m}^{-3}\right)\end{array}$ & 0.6 & $\begin{array}{c}\text { Tensile Damping } \\
\left(\mathrm{Kg} \times \mathrm{m}^{2}\right)\end{array}$ & 12.0 \\
\hline Length $(\mathrm{mm})$ & 3500.0 & $\begin{array}{c}\text { Bending Damping } \\
\left(\mathrm{N} \times \mathrm{S} \times \mathrm{m}^{2}\right)\end{array}$ & $1 \times 10^{-4}$ \\
\hline Discrete Number & 200.0 & $\begin{array}{c}\text { Contact stiffness } \\
\left(\mathrm{N} \times \mathrm{mm}^{-1}\right)\end{array}$ & 4000.0 \\
\hline $\begin{array}{c}\text { Thermal } \\
\text { Conductivity } \\
\left(\mathrm{mW} / \mathrm{mm}^{\circ}{ }^{\circ} \mathrm{C}\right)\end{array}$ & 0.26 & $\begin{array}{c}\text { Contact damping } \\
(\mathrm{Pa} \times \mathrm{s})\end{array}$ & $5 \times 10^{4}$ \\
\hline Density $\left(\mathrm{t} \times \mathrm{mm}^{-3}\right)$ & $1.3 \times 10^{-9}$ & $/$ & $/$ \\
\hline $\begin{array}{c}\text { Specific Heat } \\
\text { Capacity } \\
\left(\mathrm{mJ} / \mathrm{t} \times{ }^{\circ} \mathrm{C}\right)\end{array}$ & 1.9 & $/$ & $/$ \\
\hline
\end{tabular}

\section{Setting Parameters of Tensioning Mechanism}

Tensioning mechanism is an important device for the belt drive system to maintain proper tension, avoid belt slippage, and maintain normal operation of the belt system. The physical and dynamic parameters of the tensioning mechanism are needed to build the transmission model. The parameters of the tensioning mechanism are shown in Table III.

TABLE III. PHYSICAL PROPERTIES AND DYNAMIC PARAMETERS OF TENSIONING MECHANISM.

\begin{tabular}{|c|c|c|c|}
\hline $\begin{array}{c}\text { Physical } \\
\text { Properties } \\
\text { Parameters }\end{array}$ & Value & $\begin{array}{c}\text { Dynamic } \\
\text { Parameters }\end{array}$ & Value \\
\hline $\begin{array}{c}\text { Length of Tension } \\
\text { Arm (mm) }\end{array}$ & 230.0 & $\begin{array}{c}\text { Travel Angle } \\
(\text { degree })\end{array}$ & 30 \\
\hline $\begin{array}{c}\text { Mass } \\
(\mathrm{Kg})\end{array}$ & 2.5 & $\begin{array}{c}\text { Friction Torque } \\
(\mathrm{N} \times \mathrm{m})\end{array}$ & 20 \\
\hline $\begin{array}{c}\text { Centre of rotation } \\
(\mathrm{mm}, \mathrm{mm})\end{array}$ & $(645.5,-215.0)$ & $\begin{array}{c}\text { Torsional Stiffness } \\
\left(\mathrm{N} \times \mathrm{m}^{\mathrm{m}} \times \mathrm{deg}^{-1}\right)\end{array}$ & 1 \\
\hline
\end{tabular}

\section{Application of Driving Speed and Load Torque}

In the process of heat source calculation, it is necessary to apply the speed on the driving pulley and load torque on the driven pulley according to the actual situation. Among them, the load torque of the driven pulley is defined as the load torque connected between the driven pulley and the corresponding mass element. Finally, the V-belt temperature rise heat source calculation model constructed in this paper based on AVL Excite TD is shown in Fig. 6.

\section{Calculation and Analysis of Heat Source under Single Working Condition}

Working temperature of V-belt is affected by the structural parameters and driving parameters of the transmission system. The structural parameters include the curvature radius of pulleys, elastic modulus of V-belt, and the length of V-belt. Driving parameters include the speed of the driving pulley, load of the driven pulley, tension, and ambient temperature.

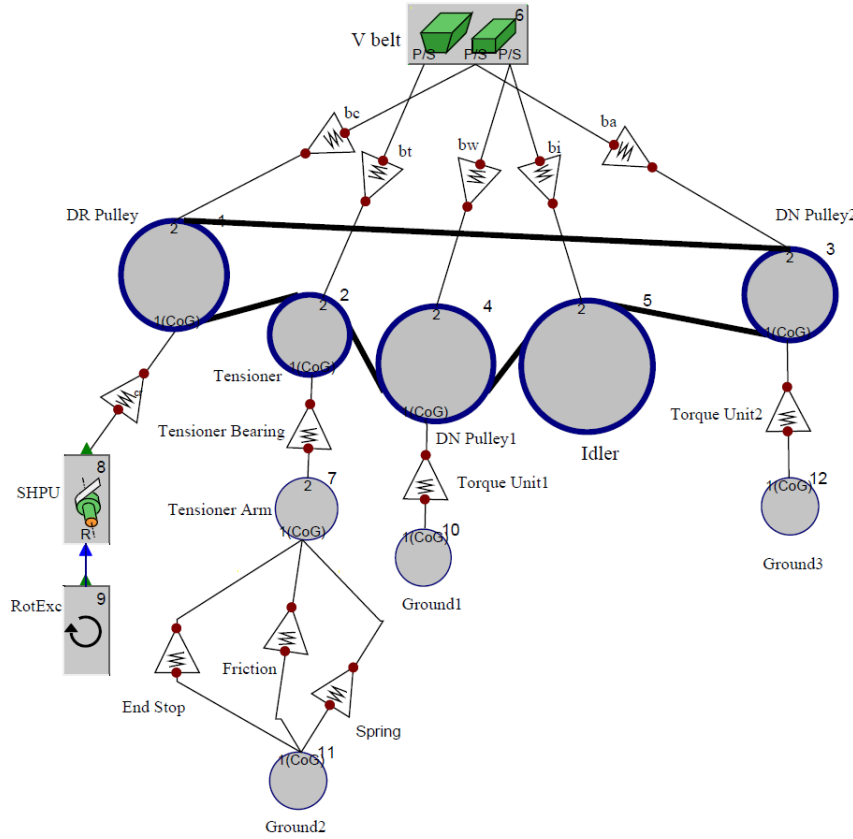

Fig. 6. Calculation model of temperature rise and heat source based on AVL Excite TD.

Due to the limitation of structure of the transmission system, the speed of driving pulley and the load of driven pulley are selected as test variables for single factor heat source calculation and analysis. For V-belt drive system of 4LZ-6A combine harvester, the reasonable range of driving pulley speed and driven pulleys load are $0 \mathrm{rpm}-1200 \mathrm{rpm}$ and 0 N.m-100 N.m, and the extreme cases, the driving pulley speed and driven pulleys load can reach $1480 \mathrm{rpm}$ and 150 N.m, respectively. The working condition information of the single factor test is shown in Table IV.

TABLE IV. WORKING CONDITION INFORMATION OF SINGLE FACTOR TEST

\begin{tabular}{|c|c|c|c|c|}
\hline Case & $\begin{array}{c}\text { Speed of } \\
\text { DR Pulley } \\
(\mathbf{r p m})\end{array}$ & $\begin{array}{c}\text { Torque of DN } \\
\text { Pulley } \mathbf{1}(\mathbf{N} \times \mathbf{~ m})\end{array}$ & $\begin{array}{c}\text { Torque of } \\
\text { DN Pulley } \\
\mathbf{2}(\mathbf{N} \times \mathbf{~ m})\end{array}$ & $\begin{array}{c}\text { Tension } \\
\text { Force } \\
(\mathbf{N})\end{array}$ \\
\hline Case 1 & 300 & 0 & 0 & 120 \\
\hline Case 2 & 500 & 0 & 0 & 120 \\
\hline Case 3 & 700 & 0 & 0 & 120 \\
\hline Case 4 & 900 & 0 & 0 & 120 \\
\hline Case 5 & 1100 & 0 & 0 & 120 \\
\hline Case 6 & 600 & 0 & 10 & 120 \\
\hline Case 7 & 600 & 0 & 30 & 120 \\
\hline Case 8 & 600 & 0 & 50 & 120 \\
\hline Case 9 & 600 & 0 & 70 & 120 \\
\hline Case 10 & 600 & 0 & 90 & 120 \\
\hline
\end{tabular}

When the driving pulley speed is a single test variable (Cases from 1 to 5), the heat source calculation results are shown in Table V and Fig. 7.

It can be seen from the results that most of the heat source of V-belt comes from the internal friction heat source and the proportion increases with the increase of the driving pulley speed. Because the bending frequency of the V-belt increases with the rotation speed of the driving wheel. This causes the hysteresis heat of the rubber to increase. The test results of the influence of driving pulley speed on power loss are the same as those of Gárdonyi, Szabó, Székely, and Kátai [30]. Due to the large relative slippage between the driving pulley and V-belt, compared with other pulleys, the external friction 
heat source value of the driving pulley is larger. Compared with driven pulley 1 , idler, and tensioner, since the load on driven pulley 2 is large, the friction loss generated is relatively large. The research of Manin, Liang, and Lorenzon shows that the external friction of the transmission belt only occurs on the pulley with resistance torque [6]. This conclusion is also verified by the heat source calculation results when the driving pulley speed changes.

When the load of driven pulley 2 is a single test variable (Cases from 6 to 10), the heat source calculation results are shown in Table VI and Fig. 8.

TABLE V. CALCULATION RESULTS OF HEAT SOURCE WHEN DRIVING PULLEY SPEED CHANGES.

\begin{tabular}{|c|c|c|c|c|c|c|c|c|}
\hline \multirow[b]{2}{*}{ Case } & \multicolumn{5}{|c|}{ External Friction (W) } & \multirow{2}{*}{$\begin{array}{c}\text { Internal } \\
\text { Friction (W) }\end{array}$} & \multicolumn{2}{|c|}{ Proportion (\%) } \\
\hline & Driving Pulley & Tensioner & DN Pulley 1 & Idler & DN Pulley 2 & & $\begin{array}{l}\text { External } \\
\text { Friction }\end{array}$ & $\begin{array}{l}\text { Internal } \\
\text { Friction }\end{array}$ \\
\hline Case 1 & 12.22 & 0.19 & 0.38 & 7.31 & 4.99 & 54.93 & 31.4 & 68.6 \\
\hline Case 2 & 21.14 & 0.13 & 0.46 & 7.33 & 7.84 & 115.72 & 24.2 & 75.8 \\
\hline Case 3 & 33.28 & 0.16 & 1.51 & 7.78 & 10.62 & 187.07 & 22.2 & 77.8 \\
\hline Case 4 & 44.47 & 0.13 & 2.35 & 9.06 & 13.84 & 260.63 & 21.1 & 78.9 \\
\hline Case 5 & 62.14 & 0.46 & 2.24 & 7.83 & 18.99 & 374.85 & 19.6 & 80.4 \\
\hline
\end{tabular}

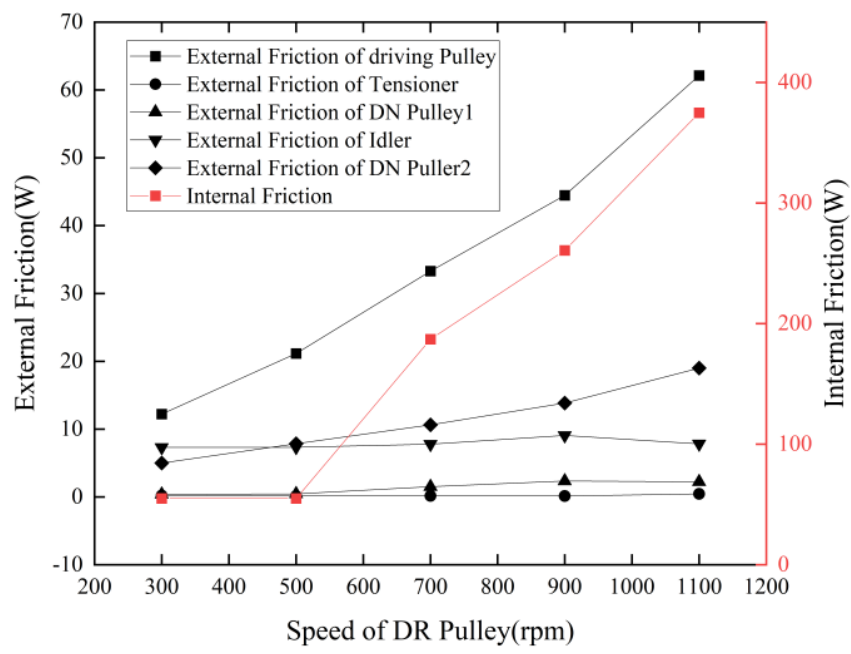

Fig. 7. Calculation results of heat source when the driving pulley speed changes.

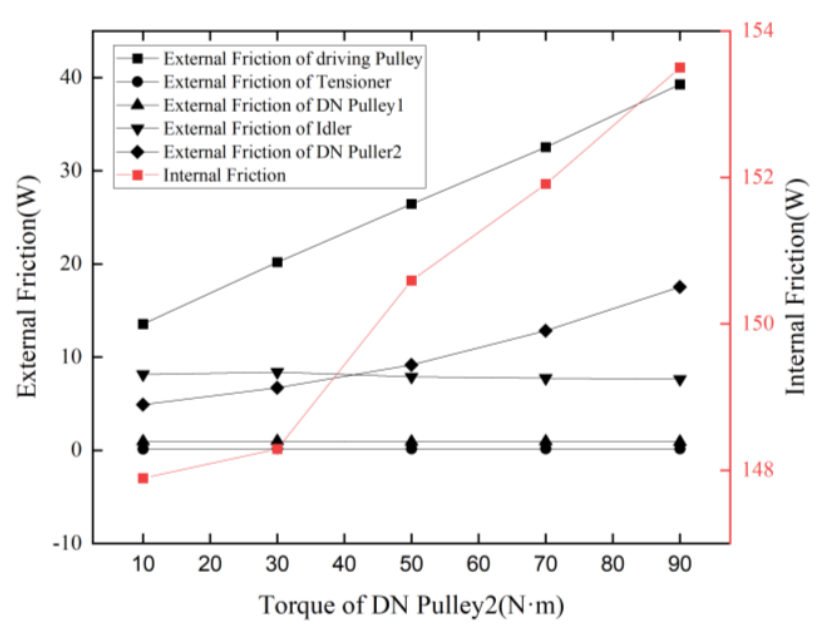

Fig. 8. Calculation results of heat source when the load torque of driven pulley 2 changes.

TABLE VI. CALCULATION RESULTS OF HEAT SOURCE WHEN LOAD TORQUE OF DRIVEN PULLEY 2 CHANGES

\begin{tabular}{|c|c|c|c|c|c|c|c|c|}
\hline \multirow[b]{2}{*}{ Case } & \multicolumn{5}{|c|}{ External Friction (W) } & \multirow{2}{*}{$\begin{array}{c}\text { Internal } \\
\text { Friction (W) }\end{array}$} & \multicolumn{2}{|c|}{ Proportion (\%) } \\
\hline & Driving Pulley & Tensioner & DN Pulley 1 & Idler & DN Pulley 2 & & $\begin{array}{l}\text { External } \\
\text { Friction }\end{array}$ & $\begin{array}{l}\text { Internal } \\
\text { Friction }\end{array}$ \\
\hline Case 6 & 13.55 & 0.14 & 0.96 & 8.15 & 4.92 & 147.89 & 15.8 & 84.2 \\
\hline Case 7 & 20.19 & 0.15 & 0.99 & 8.39 & 6.71 & 148.29 & 19.7 & 80.7 \\
\hline Case 8 & 26.44 & 0.16 & 0.93 & 7.89 & 9.16 & 150.59 & 22.8 & 77.2 \\
\hline Case 9 & 32.53 & 0.17 & 0.96 & 7.75 & 12.84 & 151.91 & 26.3 & 73.7 \\
\hline Case 10 & 39.26 & 0.16 & 0.92 & 7.63 & 17.53 & 153.50 & 29.9 & 70.01 \\
\hline
\end{tabular}

It can be obtained from the calculation results that although the internal friction heat source accounts for a larger proportion of the total heat source, the proportion of external friction heat source gradually increases as the load torque of driven pulley 2 increases. This is because the internal friction of the belt depends mostly on the bending of the belt [9] When the bending frequency of the belt remains unchanged, the internal friction value remains almost unchanged. This phenomenon is same as in the study of Silva, Manin, Andrianoely, Besnier, and Remond [9]. In addition, although the values of the external friction heat source of tensioner, driven pulley 1 , and idler are unchanged, basically, the values of driving pulley and driven pulley 2 the increase gradually with increase of the load torque of driven pulley 2 .

\section{NuMERICAL CAlCUlation OF V-Belt TEMPERATURE FIELD}

\section{A. Thermodynamic Basis of Temperature Field Calculation}

To facilitate the numerical calculation of V-belt temperature field, the following assumptions are proposed:

1. Texture of the belt and pulley was uniform, and the thermal conductivity is constant;

2. Heat transfer mode between V-belt and environment is the heat convection, heat transfer mode between $\mathrm{V}$-belt and pulleys is heat exchange, and the influence of heat radiation is ignored;

3. The contact area between V-belt, pulleys and environment does not change;

4. Under steady state condition, the tensioner is approximately regarded as a fixed wheel.

According to the energy conservation equation and Fourier heat conduction law, the steady state heat balance equation of V-belt can be expressed as [14], [31]

$$
\sum_{n=1}^{N} \alpha P_{f n}+P_{h}=A_{b r} \bar{h}_{b}\left(T_{b}-T_{a}\right),
$$

where $\alpha$ is the heat flow distribution coefficient between V-belt and pulleys, $P_{f n}$ is the total external friction heat 
source between V-belt and pulleys, $P_{h}$ is the internal friction heat source value of V-belt, $A_{b r}$ is the contact area between the outer surface of $\mathrm{V}$-belt and air, $\bar{h}_{b}$ is the equivalent thermal convection coefficient of V-belt, $T_{b}$ is the steady state temperature value of $\mathrm{V}$-belt, and $T_{a}$ is the reference temperature.

There is a heat flow distribution between friction pairs. According to the theory of elastic sliding, there is relative sliding between V-belt and pulleys. If the transmission belt is taken as a fixed reference, the elastic sliding between $\mathrm{V}$-belt and pulleys can be idealized as the process of the brake pad crossing an infinite plane. Therefore, the heat flow distribution coefficient model between the brake disc and brake pad is adopted to determine the heat flow distribution between V-belt and pulleys. The heat flow distribution coefficient between V-belt and pulleys can be expressed as [23]

$$
\alpha=\frac{q_{r}}{q_{t}}=\frac{q_{r}}{q_{r}+q_{s}}=\frac{\sqrt{\lambda_{r}+\rho_{r}+C_{r}}}{\sqrt{\lambda_{r}+\rho_{r}+C_{r}}+\sqrt{\lambda_{s}+\rho_{s}+C_{s}}},
$$

where $q_{r}$ is the thermal power per unit area flowing into V-belt, $q_{t}$ is the total power per unit area between V-belt and pulleys, $q_{s}$ is the thermal power per unit area flowing into pulleys, $\lambda_{r}$ is the thermal conductivity of $\mathrm{V}$-belt, $\lambda_{s}$ is the thermal conductivity of pulleys, $\rho_{r}$ is the density of V-belt, $\rho_{s}$ is the density of pulleys, $C_{r}$ is the specific heat capacity of V-belt, and $C_{s}$ is the specific heat capacity of pulley. The heat flux distribution coefficient $\alpha$ is $6.6 \%$ calculated by (3). In other words, most of the friction heat between the belt and the pulley is distributed to pulley and a small part to belt.

Convective heat transfer between V-belt and air can be compared to the process in which air sweeps across a plate from one side. The relationship between the heat convection coefficient and V-belt linear velocity can be expressed as [16]

$$
h_{b}=k_{1} V_{b}^{4}+k_{2} V_{b}^{3}+k_{3} V_{b}^{2}+k_{4} V_{b}+k_{5}
$$

where $k_{1}, k_{2}, k_{3}, k_{4}$, and $k_{5}$ denote the five coefficients whose values relate to the material properties of $\mathrm{V}$-belt. According to reference [14], V-belt coefficient used in this paper is as follows: $k_{1}=-6.93 \times 10^{-5}, k_{2}=7.14 \times 10^{-3}, k_{3}=0.252, k_{4}=4.3$, and $k_{5}=1.7$.

\section{B. Finite Element Model for Temperature Field Calculation}

In this paper, the finite element method is used to calculate the temperature field of V-belt. Firstly, three-dimensional dynamic model of V-belt is transformed into a two-dimensional static heat transfer model. Secondly, the equivalent heat load value is determined. Thirdly, meshing and applying boundary conditions. Finally, the simulation of the temperature field under multiple working conditions is carried out.

\section{Transformation of Equivalent Two-dimensional Static} Heat Transfer Model

In three-dimensional dynamic heat transfer model, the bending internal heat source acts on V-belt in the form of body load, and the external heat source acts on the sliding contact surface in the form of surface load. To reduce the amount of calculation and improve the simulation efficiency, three-dimensional dynamic heat transfer model is equivalent to two-dimensional static model. The internal heat source body load is converted into a surface load, and the external friction surface load is converted into a linear load, as shown in Fig. 9.

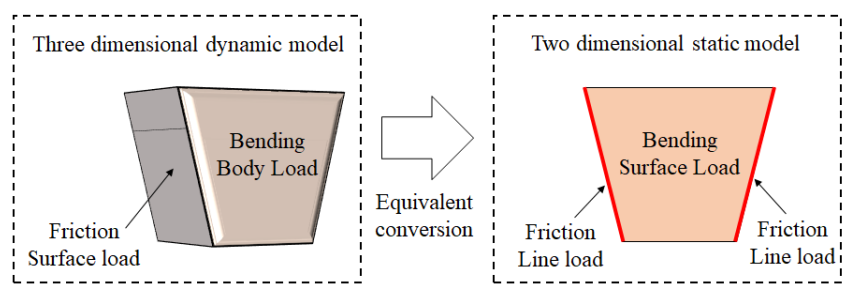

Fig. 9. Equivalent conversion of temperature rise heat source.

If the external friction heat source values of driving pulley, tensioner, driven pulley 1 , idler, and driven pulley 2 are $P_{d r}$, $P_{t n}, P_{d n 1}, P_{i d}$, and $P_{d n 2}$, respectively, the total external friction surface load $P_{f n}$ can be expressed as

$$
P_{f n}=P_{d r}+P_{t n}+P_{d n 1}+P_{i d}+P_{d n 2} .
$$

If $L_{b}$ is the length of V-belt, $L_{f}$ is the width of the friction boundary of V-belt, and $A_{b}$ is the cross-sectional area of V-belt, the equivalent linear friction load $\bar{P}_{f}$ and bending surface load $\bar{P}_{h}$ of V-belt can be expressed as:

$$
\begin{aligned}
& \bar{P}_{f}=\frac{\alpha P_{f n}}{L_{b} L_{f}}, \\
& \bar{P}_{h}=\frac{P_{h}}{L_{b} A_{b}} .
\end{aligned}
$$

According to (2), the equivalent equilibrium formula of two-dimensional V-band steady state thermal analysis can be obtained as follows

$$
\bar{P}_{f}+\bar{P}_{h}=A_{b} \bar{h}_{b}\left(T_{b}-T_{a}\right)
$$

\section{Determination Equivalent Thermal Load}

According to Table I, Table II, and (3), the heat flow distribution coefficient between $\mathrm{V}$-belt and pulleys is $6.6 \%$. On the basis of the national standard ISO 5289:1992, "Agricultural, machinery-Endless hexagonal belts and groove sections of corresponding pulleys" and transmission structure, $L_{b}=3532 \mathrm{~mm}, L_{f}=60 \mathrm{~mm}$, and $A_{b}=740 \mathrm{~mm}^{2}$ are obtained. Then two-dimensional equivalent thermal load value is determined according to (4), (6), (7), and Tables VI and VII, as shown in Table VIII. 
TABLE VIII. TWO-DIMENSIONAL EQUIVALENT THERMAL LOAD UNDER DIFFERENT CONDITIONS.

\begin{tabular}{|c|c|c|c|}
\hline Case & $\begin{array}{c}\overline{\boldsymbol{P}}_{f} \\
\left(\mathbf{W} \times \mathbf{m}^{-\mathbf{2}}\right)\end{array}$ & $\begin{array}{c}\overline{\boldsymbol{P}}_{\boldsymbol{h}} \\
\left(\mathbf{W} \times \mathbf{~ m}^{-\mathbf{3}}\right)\end{array}$ & $\begin{array}{c}\boldsymbol{h}_{\boldsymbol{b}} \\
\left(\mathbf{W} \times \mathbf{m}^{-\mathbf{2}} \times \mathbf{K}^{-\mathbf{1}}\right)\end{array}$ \\
\hline Case 1 & 118.4 & 21016.7 & 6.57 \\
\hline Case 2 & 174.1 & 44274.7 & 10.2 \\
\hline Case 3 & 251.7 & 71573.4 & 14.0 \\
\hline Case 4 & 329.6 & 99717.6 & 18.2 \\
\hline Case 5 & 432.5 & 143418.5 & 22.7 \\
\hline Case 6 & 130.8 & 56583.1 & 12.1 \\
\hline Case 7 & 171.9 & 56736.1 & 12.1 \\
\hline Case 8 & 210.4 & 57616.1 & 12.1 \\
\hline Case 9 & 256.0 & 58121.1 & 12.1 \\
\hline Case 10 & 309.1 & 58729.5 & 12.1 \\
\hline
\end{tabular}

\section{Meshing and Applying Boundary Conditions}

Since the contact between V-belt and each pulley is the same, this paper takes the cross section of driven pulley 2 as an example to construct the belt transmission steady state temperature field calculation model. The setting of boundary conditions is shown in Fig. 10. The heat conduction boundary is defined on the contact surface between the pulley groove and V-belt, and an equivalent friction external heat source is applied. An equivalent bending internal heat source is applied to V-belt body. At the same time, the convective heat transfer is defined on the contact boundary between V-belt and pulley.

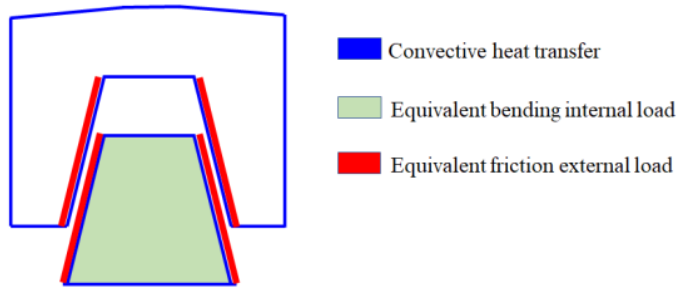

Fig. 10. Setting of boundary conditions.

\section{Simulation Results of Temperature Field under Multiple Working Conditions}

To explore the influence of different speed levels of driving speed on steady state temperature of V-belt, the finite element simulation is carried out according to the boundary conditions of cases from 1 to 5 in Table VIII, and the simulation results are shown in Fig. 11(a).

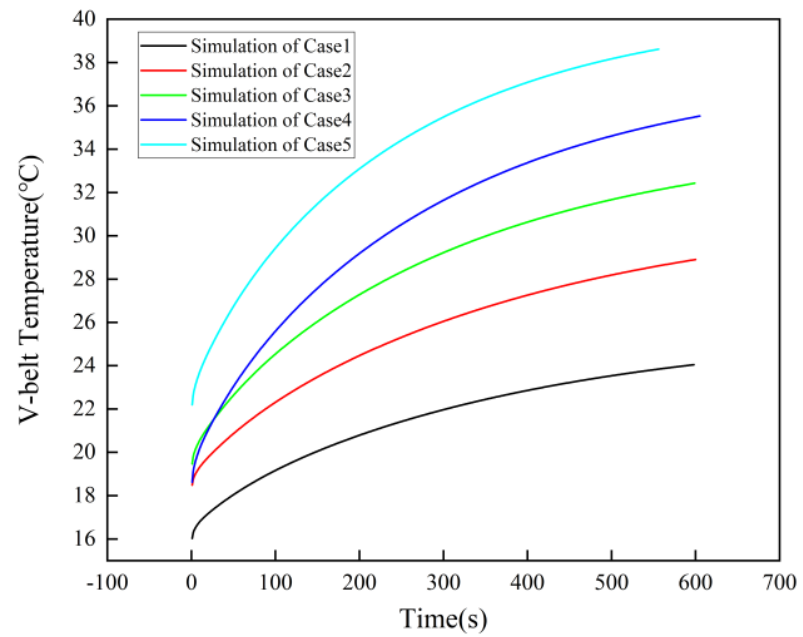

(a)

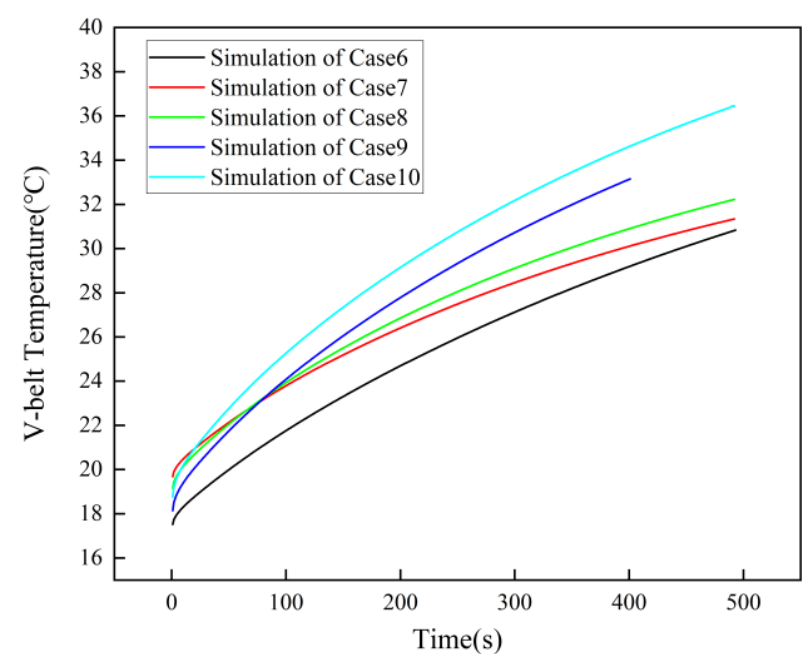

(b)

Fig. 11. Simulation results: (a) the influence of driving speed on temperature of V-belt and (b) the influence of load torque on the temperature of V-belt.

As can be seen from Fig. 11(a), the different levels of driving speed have a significant effect on the temperature of $\mathrm{V}$-belt. For the sake of analysis, the temperature field of $\mathrm{V}$-belt, the temperature rise process of $\mathrm{V}$-belt is divided into two parts: one is the unsteady state process of rapid temperature rise, and the other is steady state process of slow temperature rise. At the same speed level, the temperature of V-belt gradually increases and tends to be stable. In addition, at different speed levels, the temperature values of unsteady and steady state increase with the increase of driving speed.

Similar to the effect of driving speed, the effect of load torque on the temperature of V-belt is shown in Fig. 11(b).

\section{EXPERIMENTAL VERIFICATION}

\section{A. Experimental Setup and Instrumentation}

In this study, the setup shown in Fig. 12 and schematically depicted in Fig. 13 is built according to Table I, Table II, and Table III to verify the temperature field calculation model of multiwheel V-belt. B-type V-belt is used to transmit power between pulleys. The belt drive is actuated by an electric motor having a maximum power output of $22 \mathrm{~kW}$. A frequency converter is used to control the angular velocity of the driver pulley. Braking torque is applied to the driven pulley 2 by means of a magnetic power break. The braking torque of the magnetic powder brake is regulated by a controllable power supply. In this way, different levels of breaking torque can be provided. The maximum braking torque capacity is 124 N.m.

The elastic slippage between $\mathrm{V}$-belt and idler is negligible as a consequence of no braking torque. Consequently, the speed of V-belt is assumed to be equal to that of the idler. To obtain the speed of the transmission system and V-belt, a hall sensor is installed at the driving pulley and idler, respectively. Additionally, a near-infrared sensor is installed at the driven pulley 2 to obtain steady state temperature of V-belt under different working conditions.

The braking torque of driven pulley 2 is obtained by the modified pulley [32]. The torque sensor consists of a stator, rotor, and detection circuit, as shown in Fig. 14. The power supply and data transmission between the stator and rotor are realized by electromagnetic induction. Detection circuit is 
composed of foil gauges, signal amplifier, and antenna. The foil gauge is pasted on the rotor. When the rotor is twisted, the resistance of the foil gauge changes. The resistance amplified by the signal amplifier is transmitted to the transmitter unit through an induction loop between the rotor and the stator.
Motor controller and controllable power supply are connected to CAN-bus through a serial port to CAN module. Data measured by the hall sensors, infrared sensor, and torque are processed in microprocessors to be converted to digital the data, then data from CAN-bus is transferred to a computer using a data acquisition software, LabVIEW ${ }^{\mathrm{TM}}$.

Fig. 12. The experiment setup.

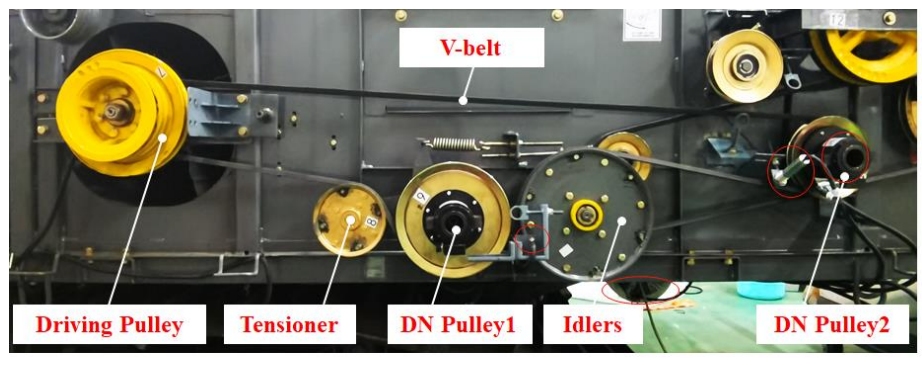

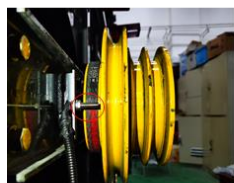

Hall Speed Sensor

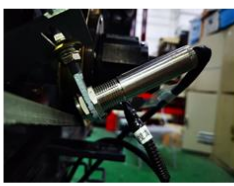

Infrared Sensor

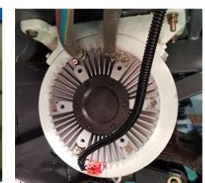

Magnetic Power Break

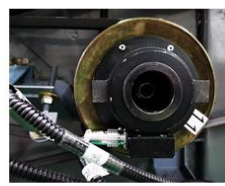

Torque Sensor

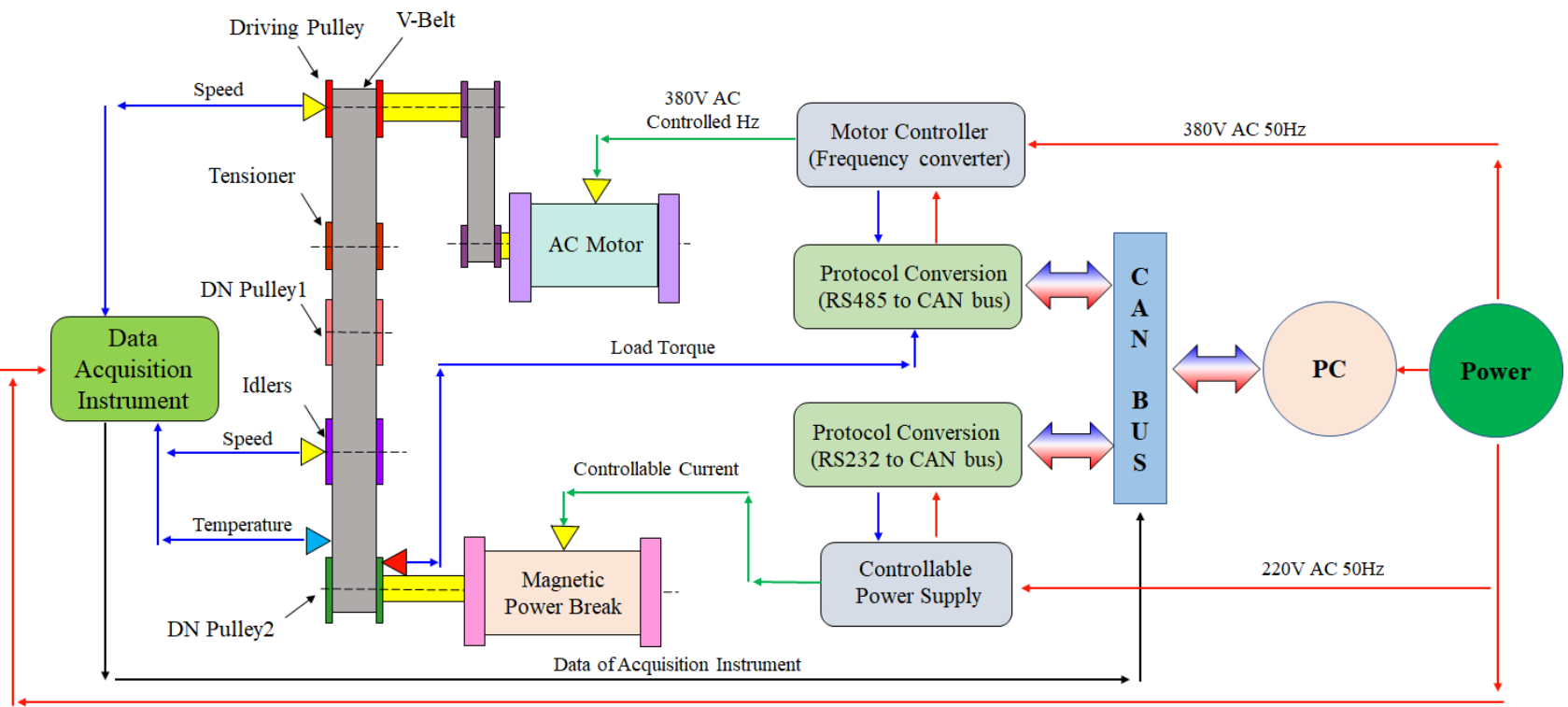

$12 \mathrm{~V} \mathrm{DC}$

Fig. 13. Schematic of the experimental setup and the instruments.

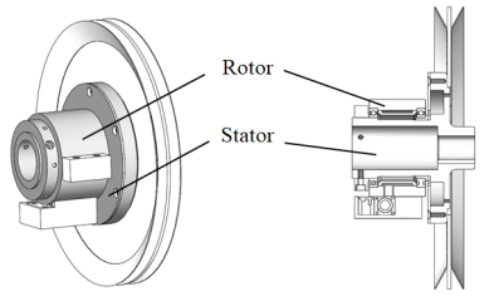

(a)

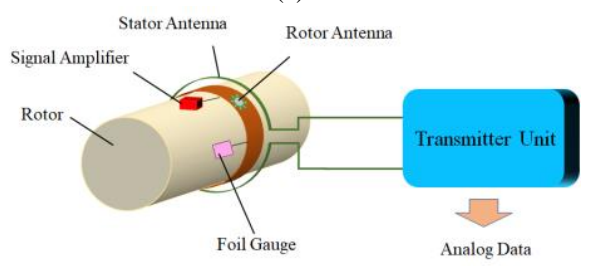

(b)

Fig. 14. Structure diagram of torque sensor: (a) Overall structure diagram of torque sensor; (b) Schematic diagram of torque sensor.

\section{B. One-factor-at-a-time (OFAT) Test Results}

OFAT test is carried out in the indoor environment with $16.2{ }^{\circ} \mathrm{C}$ ambient temperature and $18.4 \%$ relative humidity, according to the parameters in Table IV. After each test, $\mathrm{V}$-belt temperature is reduced to about room temperature by natural cooling.

The individual effects of driving speed on V-belt temperature are first determined by conducting tests (from Case 1 to Case 5 in Table IV) in which load of driven pulley 1 and driven pulley 2 are zero. The results are shown in Fig. 15(a). Compared with the simulation results in Section III, the temperature rise trend of V-belt is consistent. As can be seen from Fig. 15(a), the temperature of V-belt first increases rapidly, then increases slowly, and finally tends to be stable at the same speed level. At different speed levels, the steady state temperature value of $\mathrm{V}$-belt becomes larger as the speed increases. 
The effects of load torque on V-belt temperature were secondly determined by conducting tests (from Case 6 to Case 10 in Table IV) in which the load of driven pulley 1 is zero and the driving speed is $600 \mathrm{rpm}$. The results are shown in Fig. 15(b). From Fig. 15(b), it can be seen that the temperature of V-belt gradually increases and tends to be stable at the same torque level. In addition, the steady state temperature of V-belt increases with the increase of torque under different torque levels.

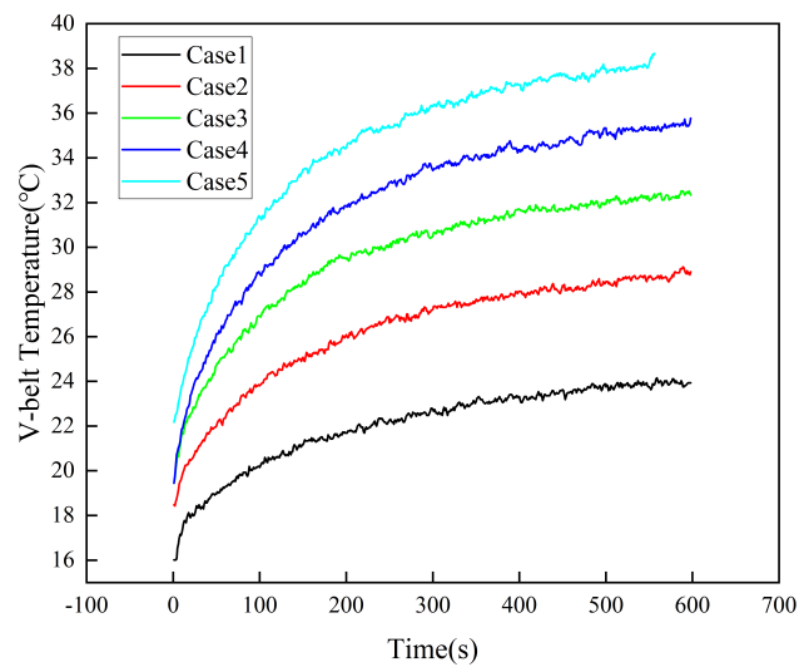

(a)

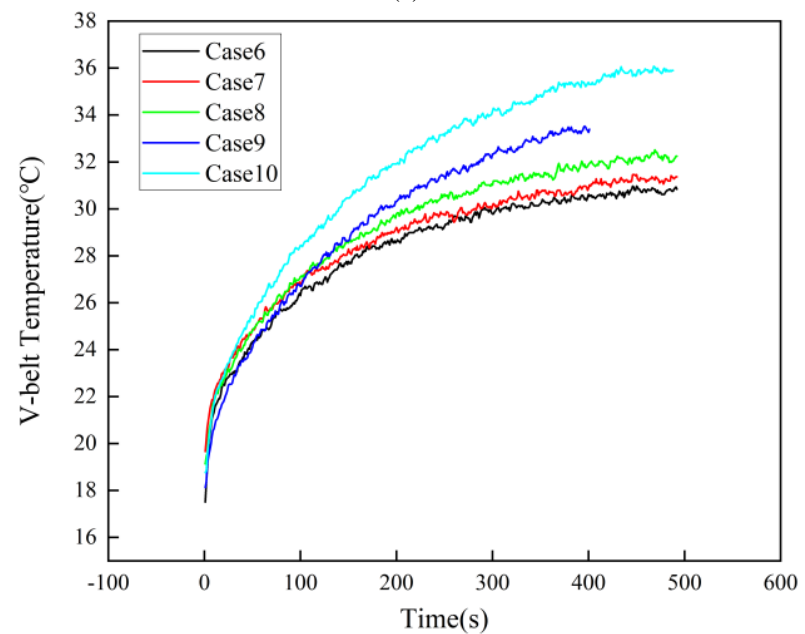

(b)

Fig. 15. Test results: (a) the influence of driving speed on the temperature of $\mathrm{V}$-belt and (b) the influence of load torque on the temperature of V-belt.

In summary, the temperature rise curve of the belt is approximately logarithmic. This can be explained from the perspective of heat generation and heat dissipation of the transmission belt. At the beginning of the test, the convective heat transfer between the belt and air is small, and most of the heat sources are used to increase the internal energy of the belt. Therefore, the belt temperature rise rate is fast. In unsteady state process, with the increase of temperature of the belt, the convective heat transfer intensity between the belt and air gradually increases, the heat source value used to increase the internal energy of the belt gradually decreases, and the temperature rise rate of the belt gradually decreases. In steady state process, the total heat source value of the belt is equal to the convective heat transfer value between the belt and air, the internal energy of the belt does not change, and the temperature of the belt does not change.

\section{Comparison Between Simulation and Experiment of Temperature Field under Multiple Working Conditions}

To evaluate the accuracy of the simulation model of the temperature field of multiwheel $\mathrm{V}$-belt system, the parameter $\Delta T$ is used in this paper. $\Delta T$ can be expressed as

$$
\Delta T=T_{\text {test }}-T_{\text {simulation }}
$$

where $T_{\text {test }}$ is the test temperature and $T_{\text {simulation }}$ is the simulation temperature. The calculation results of $\Delta T$ at different speed and load torque levels are shown in Fig. 16. As can be seen from Fig. 16, similar to the simulation results in Section III, the change of $\Delta T$ has two processes: unsteady process and steady process.

It is an unsteady process in the range of $0 \mathrm{~s} \sim 475 \mathrm{~s}$. In this process, $\Delta T$ first increased and then decreased. When the driving speed is a single variable, the maximum value of $\Delta T$ is $3.43{ }^{\circ} \mathrm{C}$, about $103 \mathrm{~s}$, as shown in Fig. 16(a). When the load torque is a single variable, the maximum value of $\Delta T$ is $4.77^{\circ} \mathrm{C}$, about $100 \mathrm{~s}$, as shown in Fig. 16(b).

After $475 \mathrm{~s}$, there is a steady state process. In this process, $\Delta T$ tends to be stable. When the driving speed is a single variable, the mean value of $\Delta T$ is $0.17^{\circ} \mathrm{C}$, as shown in Fig. 16(a). When the load torque is a single variable, the average value of $\Delta T$ is about $0.14^{\circ} \mathrm{C}$, as shown in Fig. 16(b).

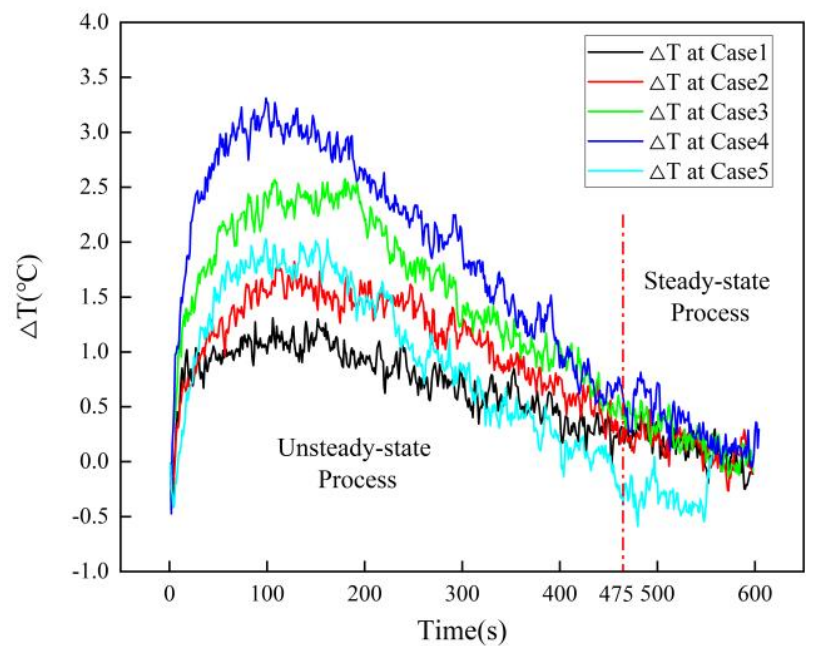

(a)

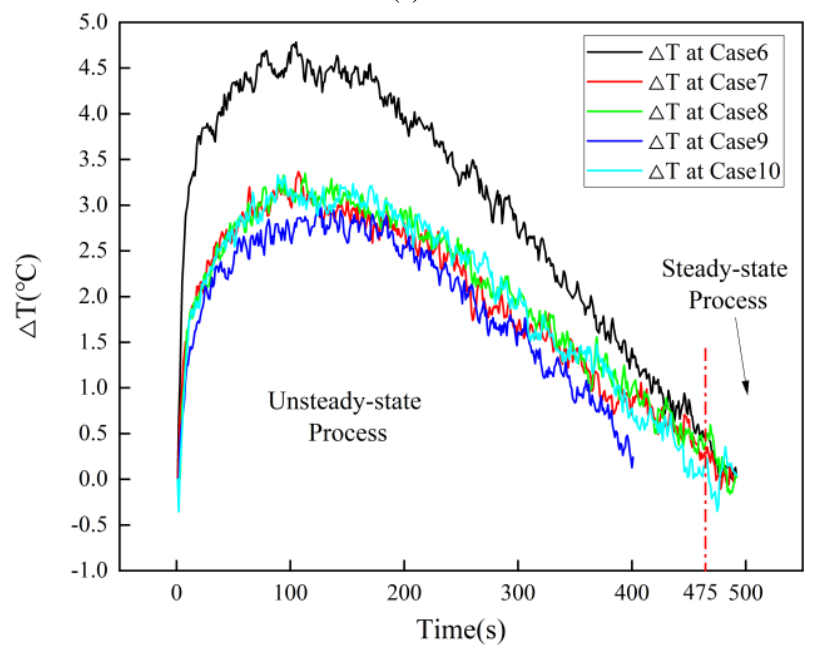

(b)

Fig. 16. Comparison between simulation results and test results: (a) the influence of driving speed on the temperature of V-belt and (b) the influence of load torque on the temperature of V-belt. 
In summary, in any case, $\Delta T$ first increased, then decreased, and finally stabilized. It shows that the difference between the calculated value and experimental value in the unsteady state process is greater than that in steady state process. This is because only the heat flux distribution of friction heat between the belt and pulleys are considered in the simulation of unsteady state process, and the influence of heat conduction between the belt and pulleys are ignored. According to (3), 93.4\% of the external friction heat is used to increase the internal energy of pulleys, and the specific heat capacity of the pulley is 3.70 times of that of belt. This will cause the pulley to have a higher temperature value than belt. Due to the temperature difference between the belt and pulleys, some of the heat will flow from the pulleys into belt. The conclusion of reference [16] showed that "contribution of external friction heat load to the temperature rise of the belt is greater than that of the internal friction heat load in the range of $0-157 \mathrm{~s}$; and the internal friction heat load plays a leading role in the range of 157-600 s". Therefore, the difference between the calculated value and experimental value is the largest at about $168 \mathrm{~s}$, and the difference between the calculated value and experimental value is getting bigger and bigger in the range of $0 \mathrm{~s}-157 \mathrm{~s}$, and smaller and smaller in the range of $157 \mathrm{~s}-600 \mathrm{~s}$.

In summary, the accuracy of the calculation model of V-belt temperature field in steady state stage is better than that in unsteady state stage.

High temperature fault of V-belt is a common fault in transmission system of harvester. A higher belt temperature leads to the degradation of polymer molecule chains to the aging of the rubber, thereby significantly affecting the service life of the V-belt [33]. A rule of thumb is that an increase of $18{ }^{\circ} \mathrm{F}$ in internal belt temperature will reduce the belt life by $50 \%$ [34], [35]. In addition, on the basis of lifetime data at the reference temperature, the fatigue life of the transmission belt at any temperature can also be calculated through time-temperature superposition model [36] and linear relationship model [37]. Therefore, the lifetime of V-belt can be predicted according to steady state temperature value of belt. Under extreme working conditions, the transmission belt is prone to high temperature failure. For the transmission system of this paper, the temperature of V-belt calculated in extreme cases by the temperature field calculation model is shown in Fig. 17.

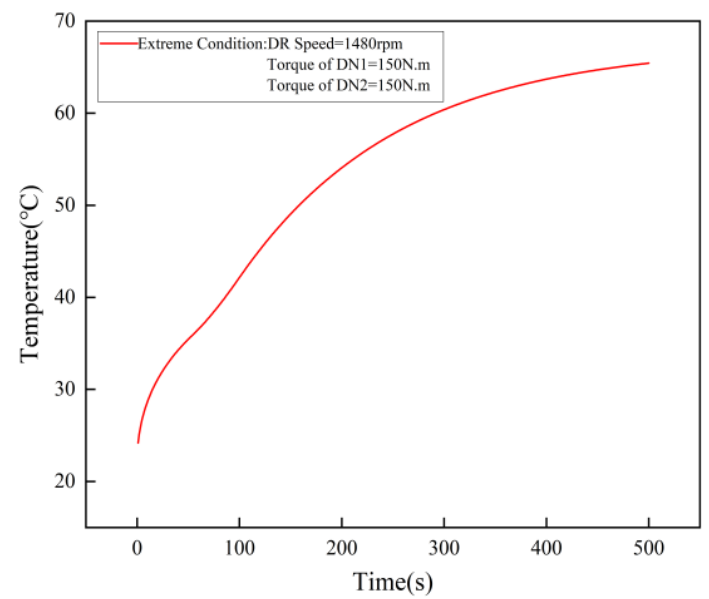

Fig. 17. Temperature rise curve under extreme working conditions calculated by the model.
It can be seen from Fig. 17 that the steady state temperature under extreme conditions is about $65.4{ }^{\circ} \mathrm{C}$. Compared with from Case 1 to Case 10, the service life under extreme conditions is greatly shortened. Therefore, extreme cases should be avoided to improve the service life of belt.

\section{CONCLUSIONS}

1. Based on the analysis of heat source in the temperature field of transmission belt, the calculation model of temperature rise heat source of V-belt is established in the AVL Excite TD by setting the physical parameters of transmission system, parameters of tensioning mechanism, and applying the driving speed and load torque. The calculation results show that the internal friction heat source of V-belt accounts for more than $65 \%$. When the driving speed is the only variable, the proportion of internal friction heat source increases with the increase of rotational speed. When the load torque is the only variable, the proportion of external friction heat source increases with the increase of torque.

2. On the basis of analysing the heat balance equation of V-belt, determining the heat flow distribution coefficient and convective heat transfer conditions, the finite element calculation model of temperature rise of $\mathrm{V}$-belt is established, and the temperature field of V-belt is calculated under multiple working conditions. The results show that the temperature of V-belt gradually increases and tends to be stable at the same speed or load torque level. In addition, at different speed of load torque levels, the temperature values of unsteady and steady state increase with the increase of driving speed or load torque. 3 . To verify the calculation model of temperature field of multiwheel V-belt, this paper carries out the experimental verification. The experimental results show that in the unsteady process, the error of model calculation is large, and the maximum error is $4.77^{\circ} \mathrm{C}$. In the steady state process, the error of the model is small, and the average error is about $0.15^{\circ} \mathrm{C}$. The accuracy of the calculation model of V-belt temperature field in steady state stage is better than that in unsteady state stage

4. The lifetime of the belt is negatively correlated with temperature. Through the advanced calculation model of V-belt temperature field, the steady state temperature of the transmission belt under specific working conditions can be predicted. It has a very important guiding significance for reasonable selection of operating parameters and improvement of service lifetime of belt.

\section{CONFLICTS OF INTEREST}

The authors declare that they have no conflicts of interest.

\section{REFERENCES}

[1] B. Xu, X. Ni, Y. Wang, Y. Wang, Y. Liu, and X. Wang, "Optimization of threshing quality control strategy based on type-2 fuzzy logic controller", Elektronika ir Elektrotechnika, vol. 26, no. 2, pp. 15-23, 2020. DOI: 10.5755/j01.eie.26.2.25924.

[2] J. Fu, Z. Chen, L. Han, and L. Ren, "Review of grain threshing theory and technology", International Journal of Agricultural and Biological Engineering, vol. 11, no. 3, pp. 12-20, 2018. DOI: 10.25165/j.ijabe.20181103.3432.

[3] P. Krawiec, L. Różański, D. Czarnecka-Komorowska, and Ł. Warguła, "Evaluation of the thermal stability and surface characteristics of 
thermoplastic polyurethane V-belt", Materials, vol. 13, no. 7, p. 1502, 2020. DOI: $10.3390 / \mathrm{ma} 13071502$.

[4] J. Wurm, M. Fitl, M. Gumpesberger, E. Väisänen, and C. Hochenauer, "Advanced heat transfer analysis of continuously variable transmissions (CVT)", Applied Thermal Engineering, vol. 114, pp. 545-553, 2017. DOI: 10.1016/j.applthermaleng.2016.12.007.

[5] B. G. Gerbert, "Power loss and optimum tensioning of V-belt drives", Journal of Engineering for Industry, vol. 96, no. 3, pp. 877-885, 1974. DOI: $10.1115 / 1.3438456$

[6] L. Manin, X. Liang, and C. Lorenzon, "Power losses prediction in poly-v belt transmissions: application to front engine accessory drives", in Proc. of International Gear Conference 2014: 26th-28th August 2014, Lyon, 2014, pp. 1162-1171. DOI: 10.1533/9781782421955.1162.

[7] C. A. F. Silva, L. Manin, R. G. Rinaldi, D. Remond, E. Besnier, and M.-A. Andrianoely, "Modeling of power losses in poly-V belt transmissions: Hysteresis phenomena (standard analysis)", Journal of Advanced Mechanical Design, Systems, and Manufacturing, vol. 11, no. $6, \quad$ p. JAMDSM0085, $2017 . \quad$ DOI: 10.1299/jamdsm.2017jamdsm0085.

[8] C. A. F. Silva, L. Manin, R. G. Rinaldi, D. Remond, E. Besnier, and M.-A. Andrianoely, "Modeling of power losses in poly-V belt transmissions: Hysteresis phenomena (enhanced analysis)", Mechanism and Machine Theory, vol. 121, pp. 373-397, 2018. DOI: 10.1016/j.mechmachtheory.2017.10.008.

[9] C. A. F. Silva, L. Manin, M.-A. Andrianoely, E. Besnier, and D. Remond, "Power losses distribution in serpentine belt drive: Modelling and experiments", in Proc. of the Institution of Mechanical Engineers, Part D: Journal of Automobile Engineering, vol. 233, no. 13, pp. 3424-3437, 2019. DOI: 10.1177/0954407018824943.

[10] C. A. F. Silva, M.-A. Andrianoely, L. Manin, S. Ayasamy, C. Santini, E. Besnier, and D. Remond, "Optimization of power losses in poly-V belt transmissions via genetic algorithm and dynamic programming", Mechanism and Machine Theory, vol. 128, pp. 169-190, 2018. DOI: 10.1016/j.mechmachtheory.2018.05.016.

[11] B. Balta, F. O. Sonmez, and A. Cengiz, "Speed losses in V-ribbed belt drives", Mechanism and Machine Theory, vol. 86, pp. 1-14, 2015. DOI: 10.1016/j.mechmachtheory.2014.11.016.

[12] T. H. C. Childs and D. Cowburn, "Power transmission losses in V-belt drives part 2: Effects of small pulley radii", in Proc. of the Institution of Mechanical Engineers, Part D: Transport Engineering, vol. 201, no. 1 , pp. 41-53, 1987. DOI: 10.1243/PIME_PROC_1987_201_156_02.

[13] T. H. C. Childs and D. Cowbum, "Power transmission losses in V-belt drives part 1: Mismatched belt and pulley groove wedge angle effects", in Proc. of the Institution of Mechanical Engineers, Part D: Transport Engineering, vol. 201, no. 1, pp. 33-40, 1987. DOI: 10.1243/PIME_PROC_1987_201_155_02.

[14] X. Liu and K. Behdinan, "Analytical-numerical model for temperature prediction of a serpentine belt drive system", Applied Sciences, vol. 10, no. 8, p. 2709, 2020. DOI: 10.3390/app10082709.

[15] X. Liu and K. Behdinan, "A novel analytical model for the thermal behavior of a fiber-reinforced plastic pulley in a front-end accessory drive", Advances in Mechanical Engineering, vol. 12, no. 6, 2020. DOI $10.1177 / 1687814020924492$

[16] B. Xu, Y. Liu, Y. Wang, S. Wang, and X. Wang, "Prediction and experiment on steady temperature field of combine drive belt", Transactions of the Chinese Society for Agricultural Machinery, vol. 51, pp. 254-260, 2020. DOI: 10.6041/j.issn.1000-1298.2020.S1.029.

[17] P. Gárdonyi, L. Kátai, L. Székely, and I. Szabó, "Drive characteristics affecting the speed loss of V-belt drives.pdf", in Proc. of Synergy International Conference, 2017.

[18] R. Tao and Z. Hou, "Simulation on power loss of engine front end accessory belt drive systems", Journal of Tsinghua University (Science and Technology), vol. 55, no. 7, pp. 790-796, 2015.

[19] B. Balta, F. O. Sonmez, and A. Cengiz, "Experimental identification of the torque losses in V-ribbed belt drives using the response surface method", in Proc. of the Institution of Mechanical Engineers, Part D: Journal of Automobile Engineering, vol. 229, no. 8, pp. 1070-1082,
2014. DOI: $10.1177 / 0954407014555150$

[20] B. Balta, B. Balta, A. Cengiz , F. Ö. Sönmez, and A. Arı11, "Torque loss measurements on poly v-ribbed belt drive systems", in Proc. of the ASME 2012 11th Biennial Conference on Engineering Systems Design and Analysis, 2012. DOI: 10.1115/ESDA2012-82245.

[21] R. Tao and Z. Hou, "A Simulation method for the steady torque loss of engine accessory drive systems", Transactions of CSICE, vol. 33, no. 5, pp. 472-479, 2015.

[22] B. G. Gerbert, "Some Notes on V-Belt Drives", Journal of Mechanical Design, vol. 103, no. 1, pp. 8-18, 1981. DOI: 10.1115/1.3254892.

[23] W. Li, X. Zhang, Y. Shang, Q. Chen, C. Chen, and Z. Xin, "Investigation of dynamic heat generation and transfer behavior and energy dissipation for nonlinear synchronous belt transmission", Applied Thermal Engineering, vol. 144, pp. 457-468, 2018. DOI: 10.1016/j.applthermaleng.2018.08.080.

[24] R. Gao, S. Wen, A. Li, H. Zhang, W. Du, and B. Deng, "A novel low-resistance damper for use within a ventilation and air conditioning system based on the control of energy dissipation", Building and Environment, vol. 157, pp. 205-214, 2019. DOI 10.1016/j.buildenv.2019.04.041.

[25] B. G. Gerbert, "Tensile stress distribution in the cord of V-belts", Journal of Engineering for Industry, vol. 97, no. 1, pp. 14-22, 1975. DOI: $10.1115 / 1.3438528$.

[26] Z. Yin and Z. Fan, "Study on deviation of conveyor belt based on multi-body dynamics characteristics", Journal of Mechanical Engineering, vol. 56, no. 1, pp. 37-46, 2020. DOI 10.3901/JME.2020.01.037

[27] F. Pfeiffer, "Multibody systems with unilateral constraints", Journal of Applied Mathematics and Mechanics, vol. 65, no. 4, pp. 665-670, 2001. DOI: 10.1016/S0021-8928(01)00070-3.

[28] W. Xin, X. Miao, L. Weiwei, B. Miedzinski, and W. Shumao, "Optimal design of lifting platform balance control algorithm: Co-simulation and experiment", Elektronika ir Elektrotechnika, vol. 23, no. 5, pp. 3-10, 2017. DOI: 10.5755/j01.eie.23.5.19237.

[29] G. Čepon and M. Boltežar, "Dynamics of a belt-drive system using a linear complementarity problem for the belt-pulley contact description", Journal of Sound and Vibration, vol. 319, nos. 3-5, pp. 1019-1035, 2009. DOI: 10.1016/j.jsv.2008.07.005.

[30] P. Gárdonyi, I. Szabó, L. Székely, and L. Kátai, "Study of the drive characteristics affecting the power loss of V-belt drives", Acta Polytechnica Hungarica, vol. 15, no. 8, 2018

[31] S. Mukunthan, J. Vleugels, T. Huysmans, K. Kuklane, T. S. Mayor, and G. De Bruyne, "Thermal-performance evaluation of bicycle helmets for convective and evaporative heat loss at low and moderate cycling speeds", Applied Sciences, vol. 9, no. 18, p. 3672, 2019. DOI: 10.3390/app9183672.

[32] D. Sun, Y. Wang, B. Xu, Y. Fu, and X. Wang, "Mathematical model and analysis of the crushing rate of combine harvester", in Proc. of 2020 24th International Conference Electronics, 2020, pp. 1-6. DOI: 10.1109/IEEECONF49502.2020.9141622.

[33] L. Kátai, P. Szendrő, and P. Gárdonyi, "The power transmission stability and efficiency of V-belts", Progress in Agricultural Engineering Sciences, vol. 12, no. 1, pp. 25-49, 2016. DOI: 10.1556/446.12.2016.2.

[34] Rubber Manufacturers Association, Power transmission belt technical bulletin (IP-3-1), Heat resistance and low temperature properties of power transmission belts [S], Washington D.C., 1999.

[35] Gates Rubber Company, Temperature effects on rubber belt operations [DB OL]. [Online]. Available: https://ww2.gates.com/IF/facts/documents/Gf000190.pdf

[36] S. Sundararaman, J. Hu, J. Chen, and K. Chandrashekhara, "Temperature dependent fatigue-failure analysis of V-ribbed serpentine belts", International Journal of Fatigue, vol. 31, nos. 8-9, pp. 1262-1270, 2009. DOI: 10.1016/j.ijfatigue.2009.01.019.

[37] H.-J. Shim and J.-K. Kim, "Cause of failure and optimization of a V-belt pulley considering fatigue life uncertainty in automotive applications", Engineering Failure Analysis, vol. 16, no. 6, pp. 1955-1963, 2009. DOI: 10.1016/j.engfailanal.2008.10.008. 